\title{
Calcium Currents and Calcium Signaling in Rod Bipolar Cells of Rat Retinal Slices
}

\author{
Dario A. Protti and Isabel Llano \\ Arbeitsgruppe Zelluläre Neurobiologie, Max-Planck-Institut für biophysikalische Chemie, 37070 Göttingen, Germany
}

\begin{abstract}
Combined electrophysiological and imaging techniques were used to study calcium currents $\left(I_{\mathrm{Ca}}\right)$ and their sites of origin at rod bipolar cells in rat retinal slices. We report here for the first time the successful whole-cell patch-clamp recording from presynaptic boutons that were compared with somatic recordings. TTX-resistant inward currents were elicited in response to depolarization. The kinetic and pharmacological properties of $I_{\text {Ca }}$ were very similar for recordings obtained from the soma and the presynaptic terminals. $I_{\mathrm{Ca}}$ activated maximally between -30 and $-20 \mathrm{mV}$ was enhanced by Bay $\mathrm{K} 8644$ and was blocked by isradipine and nifedipine. Peak amplitude and time to peak were $-31.3 \pm 1.2 \mathrm{pA}$ and $3.2 \pm 0.2 \mathrm{msec}$ with somatic recordings ( $n=54$ ), whereas the corresponding values were $-31.6 \pm 6.1 \mathrm{pA}$ and $3.2 \pm 0.7 \mathrm{msec}$ in recordings obtained directly from terminals $(n=6)$. $I_{\mathrm{Ca}}$ showed little inactivation
\end{abstract}

Retinal bipolar cells are glutamatergic interneurons that transmit light-induced photoreceptor signals to amacrine and ganglion cells in the inner plexiform layer (IPL) via chemical synapses. On the basis of morphological and physiological criteria, two different types of bipolar cells can be distinguished: the cone bipolar cells (CBCs), which are subdivided into several classes, and the rod bipolar cells (RBCs). Unlike most mammalian neurons, bipolar cells do not produce $\mathrm{Na}^{+}$-based action potentials. Transmission of signals impinging on their dendrites is reliant on the passive electrotonic spread of the signal to the axonal terminals from which neurotransmitter is released in a graded manner.

To serve diverse physiological functions, channels and receptors are differentially distributed in distinct compartments of these cells. Receptors to neurotransmitters are clustered in dendritic postsynaptic densities in which they bind transmitter released by presynaptic neurons, as is the case for mGluR6 in RBCs (Nomura et al., 1994). In addition, neurotransmitter receptors are also present at different densities in the soma and axon (for an example of NMDA receptor distribution, see Wenzel et al., 1997). They are also found at presynaptic terminals in which bipolar cells receive reciprocal synapses from amacrine cells that exert feedback inhibition on transmitter release (Raviola and Dacheux, 1987; Tachibana and Kaneko, 1987; Zhang et al., 1997).

\footnotetext{
Received Jan. 15, 1998; revised March 6, 1998; accepted March 6, 1998.

This work was supported by the Max-Planck-Society and a von Humboldt postdoctoral fellowship to D.A.P. We are grateful to A. Marty, H. von Gersdorff, and A. Boxall for their comments on this manuscript and C. Pouzat and C. Rosenmund for discussions.

Correspondence should be addressed to Dr. Isabel Llano, Arbeitsgruppe Zelluläre Neurobiologie, Max-Planck-Institut für biophysikalische Chemie, Am Fassberg, 37070 Göttingen, Germany.

Dr. Protti's present address: Abteilung Neuroanatomie, Max-Planck Institut für Hirnforschung, Deutschordenstrasse 46, D-60528 Frankfurt, Germany.

Copyright (C) 1998 Society for Neuroscience $\quad 0270-6474 / 98 / 183715-10 \$ 05.00 / 0$
}

during sustained depolarizations. No T-type $I_{\mathrm{Ca}}$ was observed with depolarizations from $-90 \mathrm{mV}$. Concomitant with $\mathrm{Ca}^{2+}$ entry, depolarization induced the appearance of transient outward currents that resembled IPSCs and were blocked by GABA and glycine receptor antagonists, suggesting that they arise from activation of amacrine feedback synapses. Upon depolarization, intracellular $\mathrm{Ca}^{2+}\left(\left[\mathrm{Ca}^{2+}\right]_{\mathrm{i}}\right)$ rises were restricted to the presynaptic terminals with no somatic or axonal changes and were linearly dependent on pulse duration when using a low-affinity $\mathrm{Ca}^{2+}$ indicator. In cone bipolar cells, $I_{\mathrm{Ca}}$ inactivated markedly, and $\left[\mathrm{Ca}^{2+}\right]_{i}$ rises occurred in the axon, as well as in the presynaptic terminals.

Key words: retina; bipolar cells; calcium channels; presynaptic terminal; calcium imaging; CNS slices; reciprocal synapses
Because of their pivotal role in transmitter release, $\mathrm{Ca}^{2+}$ channels are expected to be present in the synaptic boutons to enable the $\mathrm{Ca}^{2+}$ influx required for exocytosis. Indeed, a preferential localization of L-type $\mathrm{Ca}^{2+}$ channels has been described in Mb1 bipolar cells of the goldfish retina, which receive a mixed input from cone and rod photoreceptors (Heidelberger and Matthews, 1992; Tachibana et al., 1993; Mennerick et al., 1997). Moreover, in dissociated rat bipolar cells L-type channels mediate $\mathrm{K}^{+}$-evoked intracellular $\mathrm{Ca}^{2+}\left(\left[\mathrm{Ca}^{2+}\right]_{\mathrm{i}}\right)$ rises in presynaptic terminals (Pan and Lipton, 1995). Work in isolated mouse retinal bipolar cells has suggested that calcium currents $\left(I_{\mathrm{Ca}}\right)$ are carried by low-voltage-activated T-type channels (Kaneko et al., 1989). It has recently been reported, however, that in addition to the T-type $I_{\mathrm{Ca}}$, a dihydropyridines (DHP)-sensitive component of $I_{\mathrm{Ca}}$ is present in bipolar cells from mouse retinal slices (de la Villa et al., 1998).

The characterization of the functional $\mathrm{Ca}^{2+}$ channel types present in the diverse neuronal elements in intact slices is a crucial requirement for the elucidation of the synaptic processing pathways in the retina. Our experiments were performed to identify $\mathrm{Ca}^{2+}$ channel type and spatial distribution in RBCs in rat retinal slices. Through the combined use of whole-cell voltageclamp and fluorometric $\mathrm{Ca}^{2+}$ imaging and direct recordings from synaptic terminals, we have found that $\mathrm{Ca}^{2+}$ influx occurs via L-type channels and that the ensuing $\left[\mathrm{Ca}^{2+}\right]_{\mathrm{i}}$ rises are restricted to presynaptic terminals.

A preliminary report of this work has been presented in abstract form (Protti and Llano, 1997).

\section{MATERIALS AND METHODS}

Retinal vertical slices were prepared from 4- to 7-week-old rats, following procedures previously described by Protti et al. (1997). The standard external solution, bicarbonate-buffered saline (BBS), consisted of (in 


\section{A}

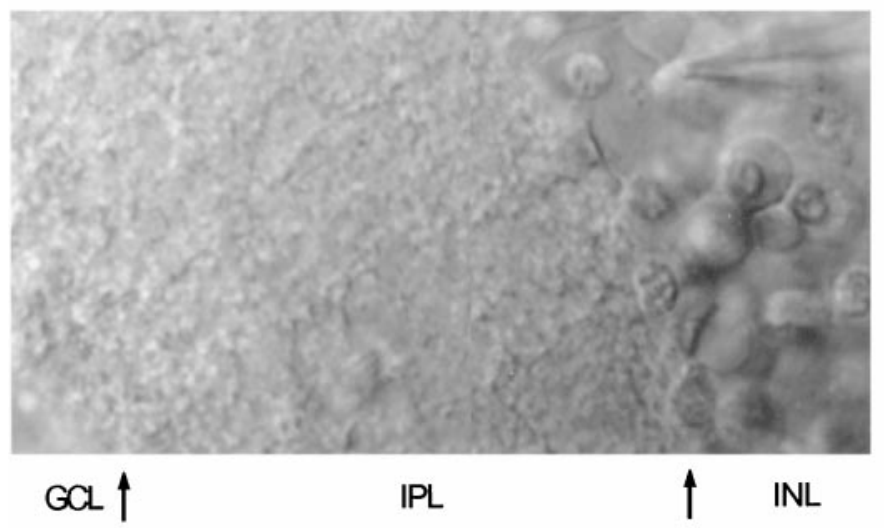

B

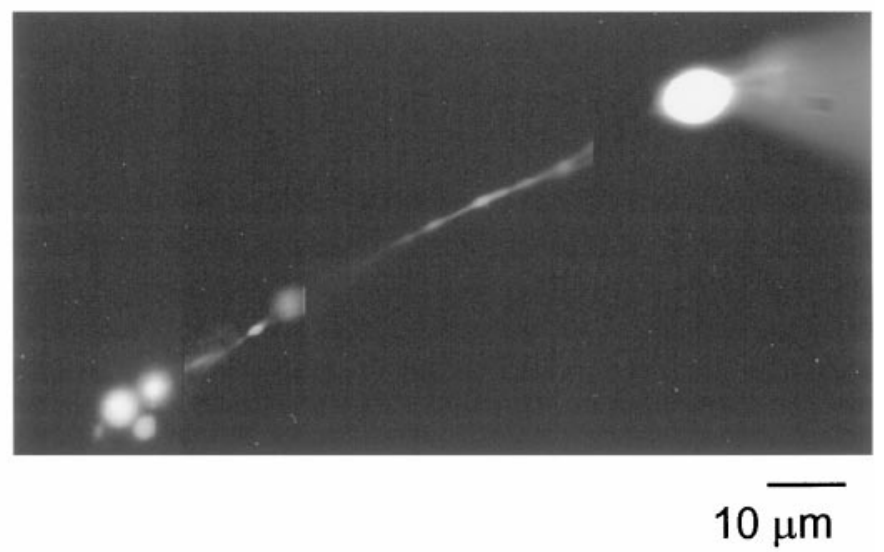

Figure 1. Identification of RBCs in rat retinal slices. $A$, Transmitted light image of a retinal slice preparation with the recording pipette placed on a cell body located in the inner nuclear layer. Arrows indicate the approximate boundaries of the different layers observed. INL, Inner nuclear layer; IPL, inner plexiform layer; $G C L$, ganglion cell layer. $B$, The same cell with its axon descending straight along the IPL and branching into three small processes in the outer part of the IPL (close to the ganglion cell layer) can be observed 10 min after breaking into the cell. A photomontage of images obtained at three different focal planes is shown. The cell was filled with $200 \mu \mathrm{M}$ OG5. Scale bar applies to $A$ and $B$.

mm): $125 \mathrm{NaCl}, 2.5 \mathrm{KCl}, 2 \mathrm{CaCl}_{2}, 1 \mathrm{MgCl}_{2}, 1.25 \mathrm{NaH}_{2} \mathrm{PO}_{4}, 26$ $\mathrm{NaHCO}_{3}$, and 10 glucose, $\mathrm{pH} 7.4$ when equilibrated with a mixture of $95 \% \mathrm{O}_{2}$ and $5 \% \mathrm{CO}_{2}$. Most of the experiments were performed with a Cs gluconate (CsGlu)-based solution containing (in mM): $132 \mathrm{CsGlu}, 5$ CsCl, 20 Cs-HEPES, $4.6 \mathrm{MgCl}_{2}, 0.1$ EGTA, $0.4 \mathrm{Na}-\mathrm{GTP}$, and $4 \mathrm{Na}-$ ATP, $\mathrm{pH}$ 7.3. In some cases, $\mathrm{K}^{+}$replaced $\mathrm{Cs}^{+}$as the main cation, and $\mathrm{Cl}^{-}$was the main anion. In some experiments, recording pipettes contained either Lucifer yellow $(0.5 \mathrm{mg} / \mathrm{ml})$ or neurobiotin $(2 \mathrm{mg} / \mathrm{ml}$; Vector Laboratories, Burlingame, CA). All other chemicals were purchased from Sigma (St. Louis, MO).

Electrophysiological recordings. Experiments were performed with the tight-seal whole-cell recording (wcr) configuration of the patch-clamp technique (Hamill et al., 1981). All experiments were done at room temperature $\left(20-25^{\circ} \mathrm{C}\right)$ using an upright microscope (Zeiss Axioskop) equipped with Nomarski differential interference contrast optics and a water immersion objective $(63 \times, 0.9$ numerical aperture). Recordings were obtained from the somata, as well as from axonal terminals of bipolar cells located in the outer part of the inner nuclear layer (INL), using an EPC-9 amplifier (Heka Electronics). Borosilicate glass pipettes with resistance of 5-8 M $\Omega$ were used for somatic recordings, whereas those used for terminal recordings had values of 18-20 M $\Omega$. Series resistances ranged from 14 to $20 \mathrm{M} \Omega$ in somatic recordings and from 38 to $60 \mathrm{M} \Omega$ in terminal recordings. Leak and capacitive currents were subtracted using the average of six hyperpolarizing pulses, and series resistance was compensated (nominally $70-80 \%$ ). Membrane potential values were corrected for junction potential. The chamber was perfused at $1-1.5 \mathrm{ml} / \mathrm{min}$ with BBS. To improve the signal-to-noise ratio, traces were averaged for each experimental condition. For electrophysiological studies, as well as during $\left[\mathrm{Ca}^{2+}\right]_{\mathrm{i}}$ imaging experiments, recordings were discontinued if the holding current at $-70 \mathrm{mV}$ exceeded $-30 \mathrm{pA}$.

After electrophysiological recordings, histological examination of neurobiotin-filled cells was performed as described by Protti et al. (1997).

Fluorometric calcium imaging. Changes in $\left[\mathrm{Ca}^{2+}\right]_{\mathrm{i}}$ were detected as changes in the fluorescence intensity of one of the following $\mathrm{Ca}^{2+}$ sensitive probes included in the patch pipette: $200 \mu \mathrm{M}$ Oregon green 488 BAPTA-5N (OG5) or $50 \mu \mathrm{M}$ Oregon green 488 BAPTA-1 (OG1). No EGTA was present in the CsGlu solution. Digital fluorescence images were obtained with image acquisition systems and a monochromatic light source for fluorescence excitation (T.I.L.L. Photonics, Planegg, Germany). The excitation pathway consisted of a $75 \mathrm{~W}$ Xe lamp focused on a scanning monochromator and coupled to the microscope by a quartz fiber and a lens. The dichroic mirror and high-pass emission filter had center wavelengths at 505 and $507 \mathrm{~nm}$, respectively. Two types of peltier-cooled, slow-scan CCD cameras were used in the present work: (1) a camera based on a Thompson 7863 frame transfer chip with $384 \times 286$ pixels (pixel size was $0.36 \mu \mathrm{m}$ after $63 \times$ magnification), and (2) a PCO SensiCam camera with $640 \times 480$ pixels (pixel size was $0.25 \mu \mathrm{m}$ after $63 \times$ magnification). Both cameras were connected to 12 bit analog-to- digital converters and had sufficient dynamic range to ensure that no saturation occurred when imaging the cell structures with large fluorescence signals, such as the cell soma. In the present study, pixel binning $(4 \times 4)$ was performed with type 1 to achieve a fast acquisition rate and to improve the signal-to-noise ratio when low concentrations of the high-affinity dye OG1 were used. Type 2 was used to acquire full images (no binning performed) and to study the spatial distribution of signals with higher spatial resolution.

The standard protocol to study $\left[\mathrm{Ca}^{2+}\right]_{\mathrm{i}}$ transients consisted of acquiring a sequence of 20 images at regular intervals. Four images were taken while the cell was held at $-70 \mathrm{mV}$, and a single depolarizing voltage step was applied at the end of the fourth image. Images were integrated from 10 to $70 \mathrm{msec}$ (see Results and figure legends). Fluorescence changes were analyzed off-line by measuring the average fluorescence in small regions of interest (ROIs; $\sim 1-2 \mu \mathrm{m}^{2}$ ) and converting it to the percent of change in fluorescence: $\Delta F / F_{\mathrm{o}}=100 \times\left(F-F_{\mathrm{r}}\right) /\left(F_{\mathrm{r}}-B\right)$, in which $F$ is the measured fluorescence signal at any given time, $F_{\mathrm{r}}$ is the average fluorescence from four consecutive images preceding the voltage step, and $B$ is the average value of the background fluorescence from four regions located in the periphery of the visual field and of equal size to the cellular ROIs. As discussed by Llano et al. (1997), the $\Delta F / F_{\mathrm{o}}$ ratio faithfully reflects changes in $\left[\mathrm{Ca}^{2+}\right]_{\mathrm{i}}$. Background values were stable during each experimental run, and the basal counts in the various ROIs analyzed were unambiguously distinguishable from the background. The mean \pm SEM for the ratio of prestimuli counts/background counts was $1.56 \pm 0.1$ for OG5 $(n=20)$ and $3.2 \pm 0.5$ for OG1 $(n=10)$.

Images displayed in the figures correspond to raw prestimuli and poststimuli data (i.e., no subtraction of background counts, averaging, or masking has been performed). They are displayed with a pseudocolor scale such that the smallest fluorescent signals are clearly apparent, whereas signals in the soma are saturated. But we stress again that the original data in which the calculation of $\Delta F / F_{\mathrm{o}}$ is based are not saturated.

To verify cell identity, long-exposure $(500 \mathrm{msec})$ images of cells filled with fluorescent $\mathrm{Ca}^{2+}$ indicators or Lucifer yellow were acquired at different focal planes at the end of the experiments. Photomontages were constructed using Adobe Photoshop software (see Figs. 1, 4, 8). Such strong illumination can lead to cell damage, as denoted by the development of large holding currents and axonal swellings.

\section{RESULTS}

\section{Identification of RBCs}

RBCs were identified from their position in the outermost part of the INL using Nomarski optics. Occasionally, their axon could be sighted as a single process running along the IPL. Further corroboration of cell type was established by filling cells with Lucifer yellow or staining with neurobiotin. Figure $1 A$ shows a transmit- 

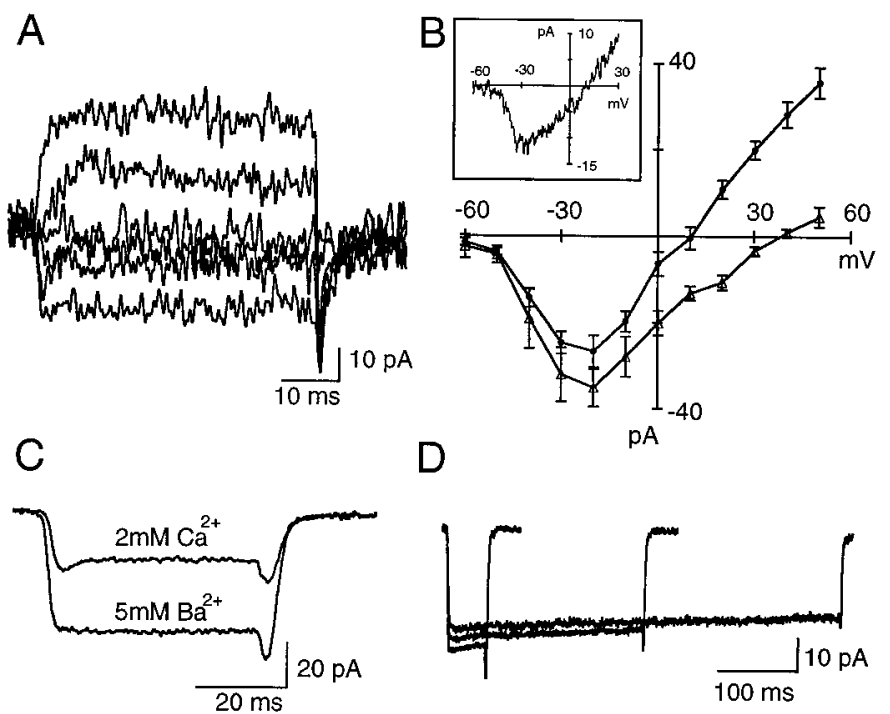

$\mathrm{D}$

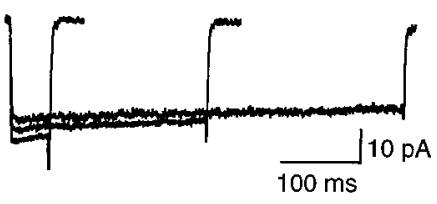

Figure 2. $I_{\mathrm{Ca}}$ in rod bipolar cells. $A$, Currents recorded under somatic whole-cell voltage clamp in a RBC dialyzed with CsGlu. Depolarizing pulses were applied from a holding potential of $-70 \mathrm{mV}$ in $20 \mathrm{mV}$ increments. $B$, Pooled data on the current-voltage relationship obtained in RBCs dialyzed with CsGlu in $2 \mathrm{~mm}$ external $\mathrm{Ca}^{2+}$ ( filled circles; $n=$ 8 ) and in $5 \mathrm{~mm}$ external $\mathrm{Ba}^{2+}$ (open triangles; $n=5$ ). Error bars indicate SEM. In both groups the activation threshold for the inward current was at $-40 \mathrm{mV}$, and peak amplitudes were reached at $-20 \mathrm{mV}$. Note the decrease in outward current when cells were bathed in external $\mathrm{Ba}^{2+} . C$, Comparison of the inward currents elicited by pulses to $-30 \mathrm{mV}\left(\mathrm{V}_{\mathrm{h}}\right.$, $-70 \mathrm{mV}$ ) in an $\mathrm{RBC}$ when the slice is perfused with $2 \mathrm{mM} \mathrm{Ca}^{2+}$ or $5 \mathrm{mM}$ $\mathrm{Ba}^{2+}$. Each trace is the average of 24 individual records. $D$, Negligible inactivation of $I_{\mathrm{Ca}}$ in RBCs. Currents were elicited by depolarizing pulses to $-20 \mathrm{mV}\left(\mathrm{V}_{\mathrm{h}},-70 \mathrm{mV}\right)$ of 50,250 , and $500 \mathrm{msec}$ duration. Each trace is the average of 24 records.

ted light picture of a $180-\mu$ m-thick slice with a patch pipette on an $\mathrm{RBC}$. The same cell can be observed in Figure $1 B, 10$ min after establishing the wcr when dialysis has taken place. Its axon descends straight along the IPL and branches into three small processes in strata 5 of sublamina $b$ of the IPL close to the ganglion cell layer, a pattern typical of rat RBCs (Euler and Wässle, 1995). Under wcr, current relaxations elicited by $10 \mathrm{mV}$ hyperpolarizing pulses deviated from monoexponential or biexponential functions, suggesting a multicompartment equivalent electrical circuit. Nonetheless, a large fraction of the current relaxation, presumably corresponding to the somatodendritic compartment, could be compensated by the slow capacitance circuit of the amplifier, yielding values of $3.29 \pm 0.09 \mathrm{pF}(n=51)$.

\section{Calcium currents in RBCs}

In agreement with previous observations (Kaneko et al., 1989; Karschin and Wässle, 1990; Klumpp et al., 1995), we found that in cells dialyzed with KCl-based internal solutions, robust slowly inactivating outward currents were activated by depolarizations to values greater than $-20 \mathrm{mV}$ applied from a holding potential of $-70 \mathrm{mV}$. No net inward currents were observed in these ionic conditions (data not shown).

To study $I_{\mathrm{Ca}}$, patch pipettes were filled with CsGlu to eliminate $\mathrm{K}^{+}$efflux and to avoid possible contamination of the inward current by $\mathrm{Ca}^{2+}$-dependent $\mathrm{Cl}^{-}$currents. These $\mathrm{Cl}^{-}$currents were observed in preliminary experiments and have been previously described in goldfish bipolar cells (Okada et al., 1995). Figure $2 A$ shows typical voltage-gated currents recorded with CsGlu pipettes. The currents are inward for potentials between
-50 and $0 \mathrm{mV}$ and outward at positive potentials. Their activation threshold was between -50 and $-40 \mathrm{mV}$, and peak amplitudes were reached between -30 and $-20 \mathrm{mV}$ in the presence of $2 \mathrm{~mm}$ external $\mathrm{Ca}^{2+}$ (Fig. $2 B$, filled circles). The peak amplitude and time to peak were $-31.3 \pm 1.2 \mathrm{pA}$ and $3.2 \pm 0.2 \mathrm{msec}$, respectively $(n=54)$. As shown in Figure $2 B$, even in cells dialyzed with CsGlu, a significant outward current developed for depolarizations $>10 \mathrm{mV}$. Such currents are likely attributable to $\mathrm{Cs}^{+}$flowing through $\mathrm{K}^{+}$channels because they are strongly reduced when the cells are bathed in $\mathrm{Ba}^{2+}$, a well known blocker of several $\mathrm{K}^{+}$channels (see the $I-V$ relationship in Fig. $2 B$, triangles). The inward currents were resistant to the sodium channel blocker TTX (400 nM) and were abolished on removal of external $\mathrm{Ca}^{2+}$, and their magnitude was increased when $5 \mathrm{~mm}$ $\mathrm{Ba}^{2+}$ was used as charge carrier (Fig. 2C).

To explore the inactivation properties of $I_{\mathrm{Ca}}$, pulses of varying duration (to $-20 \mathrm{mV}$ ) were applied. As shown in Figure $2 D, I_{\mathrm{Ca}}$ decay is small, even for $500 \mathrm{msec}$ pulses. For $100 \mathrm{msec}$ pulses, $I_{\mathrm{Ca}}$ decayed to $91.3 \pm 2.2 \%$ of its peak value $(n=7)$. Because the intracellular solution contained no exogenous $\mathrm{Ca}^{2+}$ buffer, these results indicate that $\mathrm{Ca}^{2+}$-dependent inactivation of $I_{\mathrm{Ca}}$ is minor in RBCs. After replacing external $\mathrm{Ca}^{2+}$ with $\mathrm{Ba}^{2+}$, the inactivation rate of the $\mathrm{Ba}^{2+}$ current was slightly smaller, with the inward current declining to $96.2 \pm 0.86 \%$ of its peak after a 100 msec depolarizing pulse $(n=6)$. A remarkable feature of $I_{\mathrm{Ca}}$ was its stability: some cells were recorded for $1 \mathrm{hr}$ without any noticeable decline in peak current amplitude.

The properties described above are typical of high-voltageactivated (HVA) $\mathrm{Ca}^{2+}$ currents. Depolarizing steps from -90 $\mathrm{mV}$ failed to elicit a transient current component, indicating the lack of low-voltage-activated T-type currents (data not shown).

\section{Pharmacology of calcium currents}

The biophysical properties of different HVA currents, as well as the use of specific neurotoxins and blockers, has led to the identification of several $\mathrm{Ca}^{2+}$ channel types, namely $\mathrm{L}, \mathrm{N}, \mathrm{P} / \mathrm{Q}$, and R types (Zhang et al., 1993; McCleskey, 1994; Randall and Tsien, 1995; Uchitel, 1997). L-type $\mathrm{Ca}^{2+}$ channels inactivate slowly and are sensitive to both a family of organic compounds (the DHPs that include agonists and antagonist) and to the neuropeptide calciseptine. N-type $\mathrm{Ca}^{2+}$ channels have an intermediate inactivation rate and are blocked by the neurotoxin $\omega$-conotoxin GVIA. P/Q-type $\mathrm{Ca}^{2+}$ channels inactivate very slowly. They are insensitive to DHPs and to $\omega$-conotoxin GVIA, but are sensitive to the neuropeptide $\omega$-agatoxin IVA at different doses for each channel type. R-type $\mathrm{Ca}^{2+}$ channels are resistant to all of the blockers mentioned above.

Consistent with the aforementioned slow inactivation rate that characterizes L-type $I_{\mathrm{Ca}}$, we found that the currents through $\mathrm{Ca}^{2+}$ channels in RBCs were effectively blocked by isradipine or nifedipine $(1-10 \mu \mathrm{M})$ in all cells tested. The DHP antagonists blocked $I_{\mathrm{Ca}}$ by $92 \pm 1.5 \%(n=8)$. As shown in Figure $3 \mathrm{~A}$, the small residual current recorded in the presence of DHP antagonists had the same time course as the control current. The block was only partially reversible, probably attributable to the length of time required to wash out drugs from slices. As expected for L-type $\mathrm{Ca}^{2+}$ channels, currents were enhanced by the DHP agonist Bay K 8644 (Fig. 3B). In the presence of Bay K 8644, tail currents had slower kinetics. This could reflect a genuine kinetic change, which is known to occur in the presence of this drug (Nowycky et al., 1985), as well as space-clamp failure on repolarization attributable to the increased current density. Thus, the 

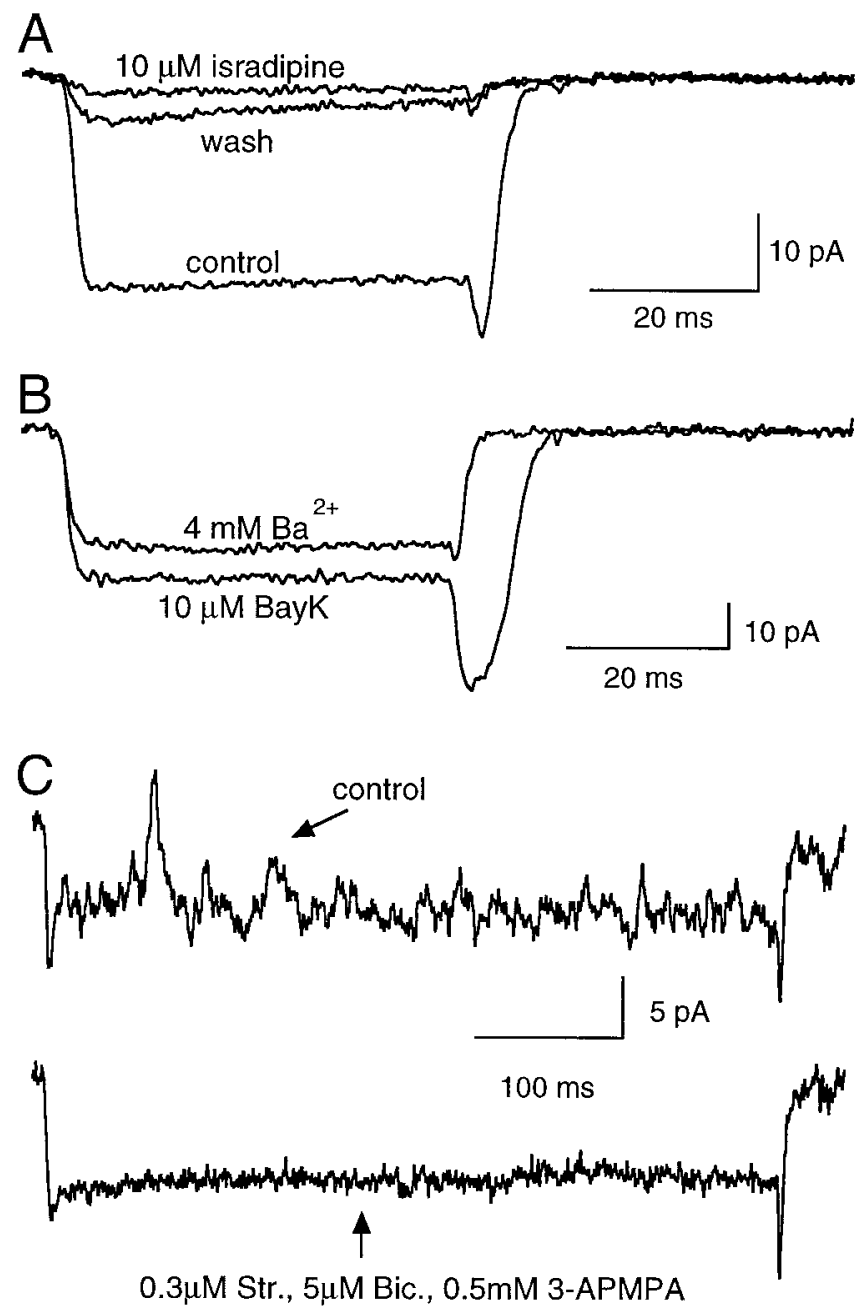

Figure 3. Pharmacological profile of the inward currents. A, The dihydropyridine antagonist isradipine $(10 \mu \mathrm{M})$ blocks the $I_{\mathrm{Ca}}$ elicited by a depolarizing step to $-30 \mathrm{mV}\left(\mathrm{V}_{\mathrm{h}},-70 \mathrm{mV}\right)$. Each trace is the average of 24 records. $B, I_{\mathrm{Ca}}$ was increased after bath application of Bay K 8644 (10 $\mu \mathrm{M})$, a specific agonist of L-type $\mathrm{Ca}^{2+}$ channels. Note the increase in amplitude and slower decay of the tail upon return to the holding potential of $-70 \mathrm{mV}$. Each trace is the average of 36 records. $C$, Evidence for the activation of reciprocal synapses. Current fluctuations superimposed upon depolarization-evoked $I_{\mathrm{Ca}}$ in control external saline (top trace) and after bath perfusion with antagonists of GABA and glycine receptors (bottom trace). Each current record is the result of a single depolarizing pulse to $0 \mathrm{mV}$. Internal solution for $A-C$ was $C$ sGlu.

large degree of block by DHP antagonists, the sensitivity to Bay $\mathrm{K} 8644$, and the kinetics of the currents recorded in the presence of DHP antagonists indicate that L-type $\mathrm{Ca}^{2+}$ channels mediate the totality of $I_{\mathrm{Ca}}$ in RBCs. Hence, the effects of other non-Ltype $\mathrm{Ca}^{2+}$ channel antagonists were not explored.

Depolarizing pulses to RBCs sometimes elicited transient current fluctuations superimposed on the pulse-evoked inward current. Such fluctuations appeared as outward deflections in the current trace. The probability of obtaining these events was higher shortly after pulse onset, but they could be observed throughout the depolarization (Fig. 3C). The temporal profile of these events resembled that of inhibitory synaptic currents recorded under low internal $\mathrm{Cl}^{-}$, suggesting that they could originate from the concomitant activity of reciprocal synapses formed between RBCs and amacrine cells. In accord with this hypothe- sis, these current fluctuations were sensitive to an antagonist cocktail of bicuculline, 3-APMPA, and strychnine $\left(\mathrm{GABA}_{\mathrm{A}}\right.$, $\mathrm{GABA}_{\mathrm{C}}$, and glycine antagonists, respectively), as shown by the example in Figure $3 C(n=3)$.

\section{Terminal recordings}

In goldfish Mb1 bipolar cells with giant synaptic terminals, most of $I_{\mathrm{Ca}}$ is carried through L-type $\mathrm{Ca}^{2+}$ channels at the presynaptic terminal (Heidelberger and Matthews, 1992; Tachibana et al., 1993). Because of the small size of synaptic boutons, direct recordings from presynaptic terminals in mammalian CNS slice preparations have been limited to the calyces of Held (BarnesDavies and Forsythe, 1995; Borst et al., 1995; Helmchen et al., 1997) and more recently to terminals of cerebellar basket cells (Southan and Robertson, 1998). Rat RBCs possess relatively large presynaptic boutons $(2.5-4 \mu \mathrm{m})$ that could allow direct recordings providing more accurate voltage control and the possibility of a straight assay for exocytosis through membrane capacitance measurements. We set out to test the feasibility of direct terminal recordings from RBCs by using a similar approach to that used for dendritic recordings in several neuronal cells, i.e., Nomarski optics to improve terminal visualization and small-tip diameter patch pipettes to avoid damage to the small structure. The price to pay for small pipette tips is a high-access resistance that might compromise voltage clamp. Nevertheless, the small maximum amplitude of $I_{\mathrm{Ca}}$ as observed in standard (somatic) recordings predicts an error of $\leq 3 \mathrm{mV}$ for recordings with access resistance of $60 \mathrm{M} \Omega$. Furthermore, because L-type $I_{\mathrm{Ca}}$ activates slowly, the temporal course of these currents may not be distorted by the filtering imposed by the high-access resistance.

Occasionally, when the retinal tissue was fully embedded in agar, i.e., it had no vitreous attached, slices of sufficient viability could be obtained to allow recording from the boutons of RBCs. It must be remarked, however, that preparations were scarce in which putative terminals could be visualized and high-resistance seals could be formed, and recording from these small structures was a difficult procedure.

Figure $4 A$ illustrates an RBC filled with Lucifer yellow via a patch pipette in the presynaptic terminal. This cell had a large terminal, and both the axon and soma were stained, allowing its positive identification as an RBC. As in the somatic recordings, inward currents were elicited in response to depolarizing pulses ranging from -30 to $10 \mathrm{mV}$, and outward currents were present at more positive membrane potentials (Fig. $4 B$ ). The properties of $I_{\mathrm{Ca}}$ in terminal recordings closely resembled those obtained in somatic recordings: (1) the $I-V$ relationship was typical of HVA $\mathrm{Ca}^{2+}$ channels (Fig. 4C); (2) the current had a slow onset (time to peak, $3.2 \pm 0.7 \mathrm{msec} ; n=6$ ); and (3) the current had little inactivation. The mean value for time to peak, as well as for the peak $I_{\mathrm{Ca}}$ amplitude from terminal recordings $(-31.6 \pm 6.1 \mathrm{pA}$, $n=6$ ), were indistinguishable from those obtained when recording with a pipette at the soma. As expected for $\mathrm{Ca}^{2+}$ channels, no inward currents were observed in $\mathrm{Ca}^{2+}$-free medium, and larger currents were obtained with $4 \mathrm{~mm}$ external $\mathrm{Ba}^{2+}$ (Fig. 4D). Responses to linear ramps (from -70 to $70 \mathrm{mV} ; 100 \mathrm{mV} / \mathrm{sec}$ ) overlapped with the $I-V$ relationship (data not shown).

The pharmacological profile of these currents was also examined. As with somatic $I_{\mathrm{Ca}}$, they were insensitive to TTX (400 nM) but were effectively blocked by the L-type $\mathrm{Ca}^{2+}$ channel blockers nifedipine $(10 \mu \mathrm{M})$ and isradipine $(1-10 \mu \mathrm{M})$. As before, Bay K $8644(1 \mu \mathrm{M})$ increased peak current amplitude as well as the magnitude of the tail currents (Fig. $4 E$ ). In the presence of Bay K 

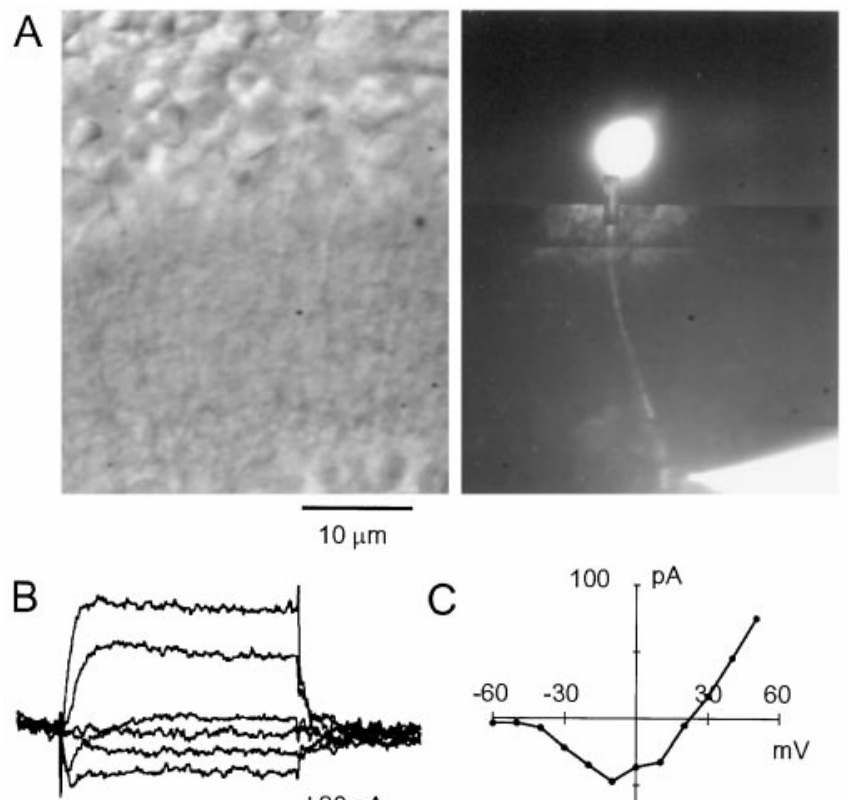

$10 \mathrm{~ms} 20 \mathrm{pA}$
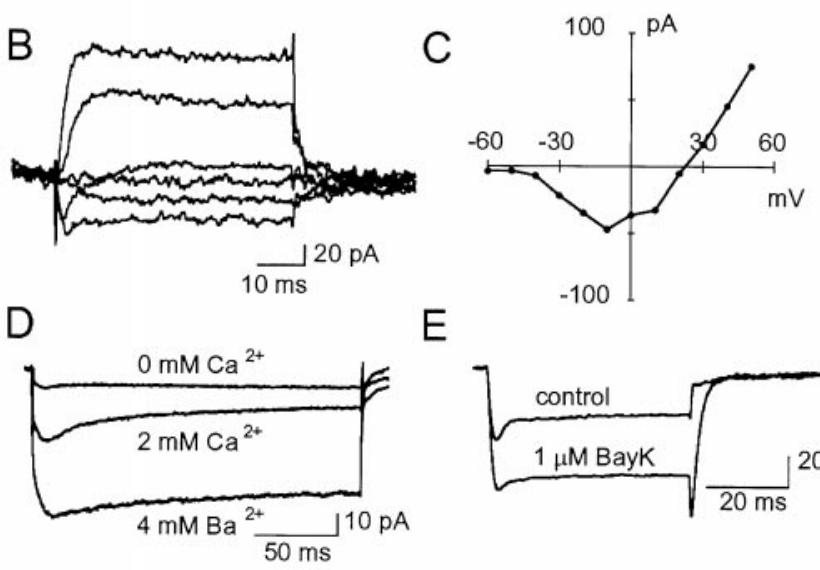

$\mathrm{E}$

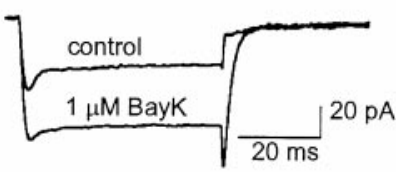

Figure 4. Terminal recordings of $I_{\mathrm{Ca}}$ obtained with a CsGlu-based internal solution. $A$, Transmitted light view of a retinal slice $(l e f t)$ in which an $\mathrm{RBC}$ has been filled with Lucifer yellow via a recording pipette located on the terminal situated in the most external part of the IPL (right). B, Current records obtained from a different cell under voltage clamp with a patch pipette placed onto the RBC terminal. Depolarizing pulses were applied from a $\mathrm{V}_{\mathrm{h}}$ of $-70 \mathrm{mV}$ in $20 \mathrm{mV}$ steps. C, Current-voltage relationship for the responses elicited in a terminal recording by depolarizing steps ( filled circles; each point is the average of two pulses) $\left(\mathrm{V}_{\mathrm{h}},-70\right.$ $\mathrm{mV})$. $D$, In a different terminal recording, the voltage-gated inward currents were abolished in the absence of external $\mathrm{Ca}^{2+}$, and their magnitude was increased when replacing $2 \mathrm{mM} \mathrm{Ca}^{2+}$ with $4 \mathrm{mM} \mathrm{Ba}^{2+}$. As in the somatic recordings, $I_{\mathrm{Ca}}$ inactivation was slow. $E, I_{\mathrm{Ca}}$ elicited by depolarizing steps from $\mathrm{a} \mathrm{V}_{\mathrm{h}}$ of $-70 \mathrm{mV}$ to $-10 \mathrm{mV}$ in terminal recording (traces are the average of 24 individual currents; same cell as in $A-C$ ) was enhanced by Bay K $8644(1 \mu \mathrm{M})$. Internal solution for $A-E$ was CsGlu.

8644, no escape of voltage control in the tail current was observed contrary to somatic recordings, suggesting a better quality of the space clamp under terminal recording conditions.

\section{$\mathrm{Ca}^{2+}$ channel localization}

The properties of depolarization-evoked $\left[\mathrm{Ca}^{2+}\right]_{i}$ rises in the somatodendritic compartment of individual neurons have been well documented (for review, see Regehr and Tank, 1994). More recently, $\left[\mathrm{Ca}^{2+}\right]_{\mathrm{i}}$ rises have been studied in axonal varicosities, branch points, synaptic boutons, and preterminal axonal segments (Borst et al., 1995; Regehr and Atluri, 1995; Callewaert et al., 1996; Mackenzie et al., 1996; Llano et al., 1997).

The data described in previous sections provide tantalizing evidence for the selective localization of L-type $\mathrm{Ca}^{2+}$ channels in the synaptic terminals of rat RBCs. To test such a suggestion, $\left[\mathrm{Ca}^{2+}\right]_{\mathrm{i}}$ was monitored through fluorescence imaging with $\mathrm{Ca}^{2+}$ sensitive probes of different $\mathrm{Ca}^{2+}$ affinity. In the first series of
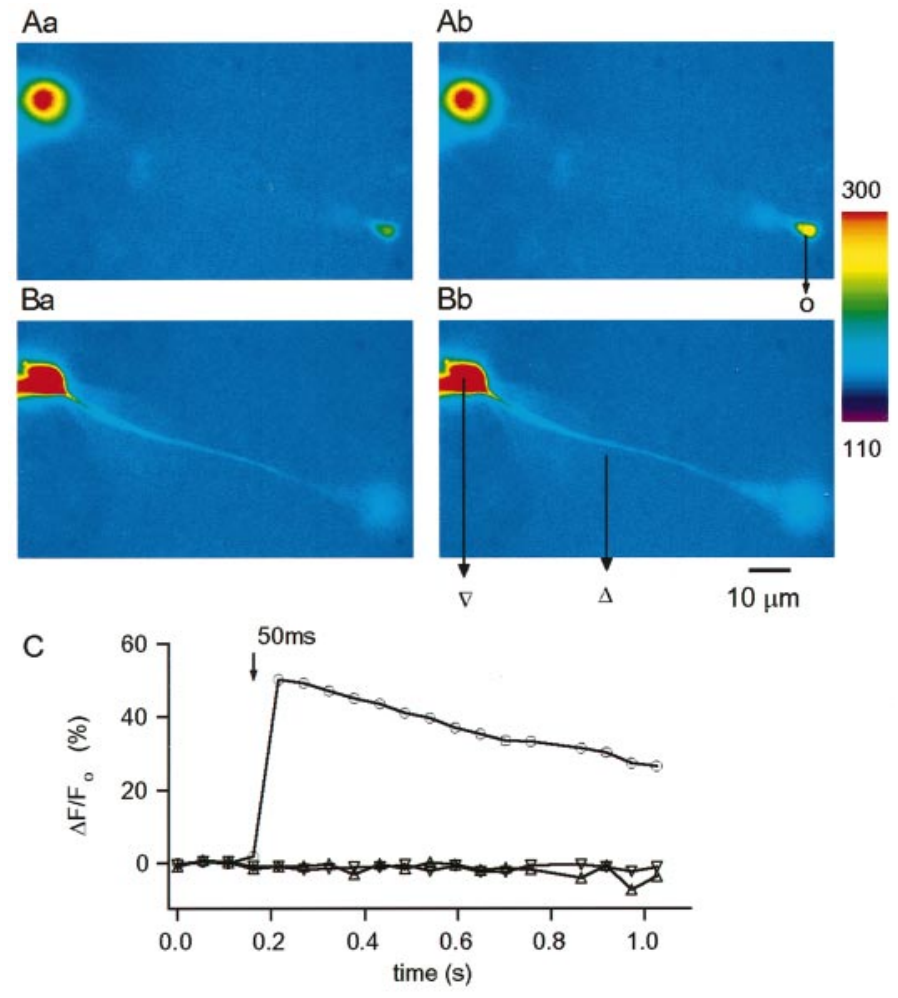

Figure 5. Spatial distribution of pulse-evoked $\left[\mathrm{Ca}^{2+}\right]_{\mathrm{i}}$ rises detected with the low-affinity dye OG5 $(200 \mu \mathrm{M}) . A, B$, Pseudocolor images of $\mathrm{Ca}^{2+}$. dependent fluorescence at rest $\left(A a, B a ; \mathrm{V}_{\mathrm{h}},-70 \mathrm{mV}\right)$ and during a 50 msec pulse to $-30 \mathrm{mV}(A b, B b) . A$ and $B$ were taken at different focal planes optimized for the terminal in $A$ and for the axon in $B$. Camera exposure time was $20 \mathrm{msec}$, and cycle time for image acquisition was 52 msec. $C$, Temporal evolution of the relative changes in fluorescence measured in discrete ROI (see Materials and Methods) as indicated in the image: triangle represents axon, inverted triangle represents soma, and circle represents terminal. The depolarization-evoked change in fluorescence is restricted to the bipolar terminal. In this and the following figures the slices were bathed in the standard control saline $\left(2 \mathrm{mM} \mathrm{Ca}^{2+}\right)$. Pipettes were filled with a CsGlu-based solution (no EGTA) as detailed in Materials and Methods.

experiments, the low-affinity indicator OG5 $\left(K_{\mathrm{d}}, \sim 20 \mu \mathrm{M}\right.$ according to Molecular Probes, Eugene, OR) was used to avoid significant interference of the dye with intrinsic $\left[\mathrm{Ca}^{2+}\right]_{\mathrm{i}}$ buffering. RBCs were dialyzed with the CsGlu solution containing OG5 $(200 \mu \mathrm{M})$, and the dye was allowed to diffuse for $5 \mathrm{~min}$ before applying stimulation protocols. Fluorescence images at different focal planes allowing visualization of the soma, axon, and synaptic terminals were acquired before and after depolarizing pulses. Figure 5 shows a representative experiment in which the focal plane was first optimized for the synaptic terminal (Fig. 5Aa,Ab) and subsequently set to image the soma and axon (Fig. $5 B a, B b$ ). Images taken before (Fig. $5 A a, B a$ ) and after (Fig. $5 A b, B b)$ a 50 msec depolarizing pulse are displayed. Figure $5 C$ plots the temporal evolution of the $\Delta F / F_{\mathrm{o}}$ that reflects changes in $\left[\mathrm{Ca}^{2+}\right]_{\mathrm{i}}$ (see Materials and Methods) at the three different locations. It is clear that the depolarization evokes $\left[\mathrm{Ca}^{2+}\right]_{\mathrm{i}}$ rises exclusively at the synaptic bouton. Neither the cell soma nor the axon increased its $\left[\mathrm{Ca}^{2+}\right]_{\mathrm{i}}$ level. This confinement of the $\left[\mathrm{Ca}^{2+}\right]_{\mathrm{i}}$ rises to the presynaptic terminals was observed in 21 RBCs. The spread of the $\left[\mathrm{Ca}^{2+}\right]_{\mathrm{i}}$ signals along the axon was not systematically examined, owing to the axon continuously changing its depth within the slice 


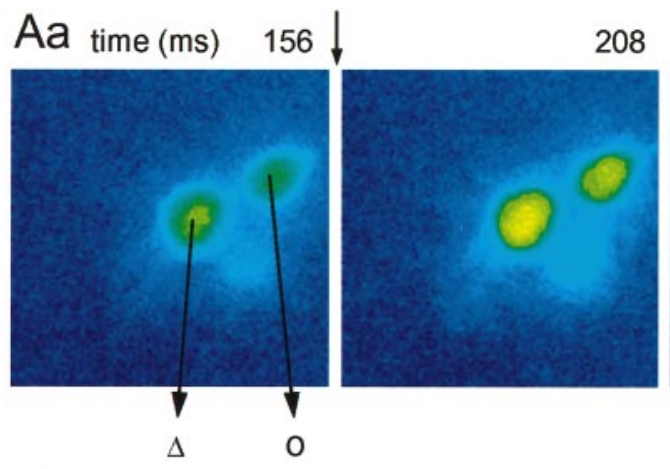

$\mathrm{Ab}$
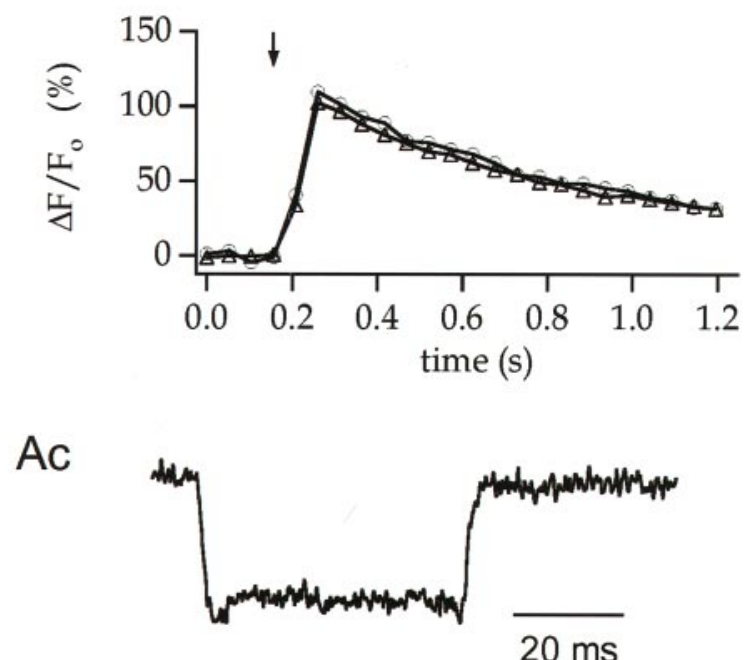

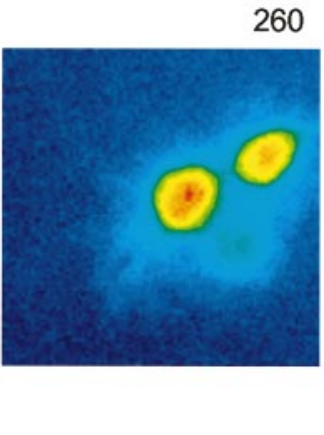

260

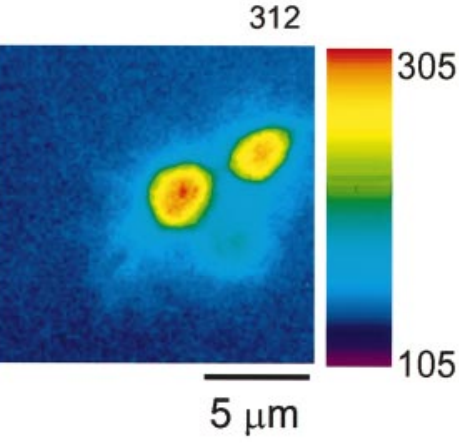

$\mathrm{Ba}$

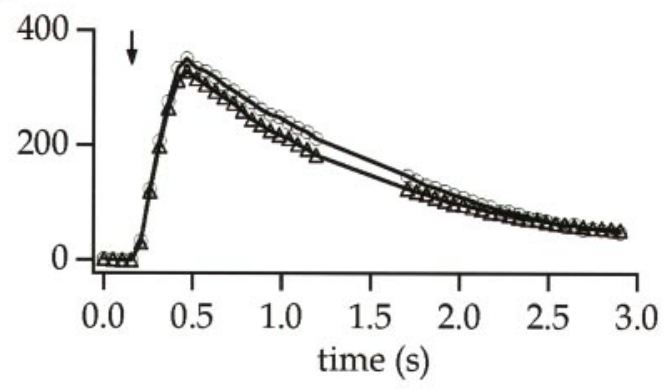

$\mathrm{Bb}$

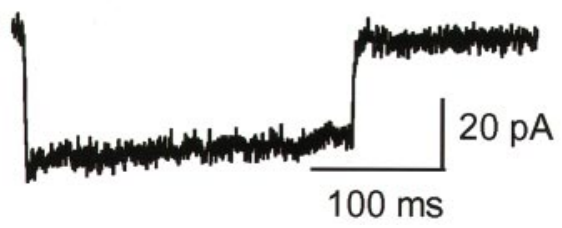

Figure 6. Modulation of terminal $\left[\mathrm{Ca}^{2+}\right]_{\mathrm{i}}$ rises by pulse duration. Aa, Time sequence of OG5 pseudocolor images from the synaptic terminal region of an RBC. The first panel corresponds to the fourth image in a series taken at rest (cycle time, $52 \mathrm{msec}$ ). A $50 \mathrm{msec}$ depolarization to $0 \mathrm{mV}$, applied immediately after the end of this image (time, 156-206 msec), elicits substantial increases in fluorescence throughout the terminals that begins to decay when the membrane potential returns to $\mathrm{V}_{\mathrm{h}} . A b, A c$, Temporal evolution of the percent of fluorescence change and the corresponding $I_{\mathrm{Ca}}$ for the experiment shown in $A a . B a, B b$, Temporal evolution of the percent of fluorescence change and the corresponding $I_{\mathrm{Ca}}$ for a $250 \mathrm{msec}$ depolarization in the same cell. Note that for a given pulse duration, the pulse-evoked changes in fluorescence have similar magnitudes and time courses in the two terminals analyzed. Internal solution was CsGlu (200 $\mu$ M OG5, no EGTA).

as it descends along the IPL. No spread of the $\left[\mathrm{Ca}^{2+}\right]_{\mathrm{i}}$ signal was observed for pulses $<100 \mathrm{msec}$ in duration at distances as short as $10 \mu \mathrm{m}$ from the terminals, however. At presynaptic boutons, the average peak $\Delta F / F_{\mathrm{o}}$ for $50 \mathrm{msec}$ depolarizing pulses was $85 \pm$ $13.9 \%(n=17)$.

As in the case of $I_{\mathrm{Ca}},\left[\mathrm{Ca}^{2+}\right]_{\mathrm{i}}$ transients in synaptic terminals were unaffected by $400 \mathrm{~nm}$ TTX but were almost completely eliminated by $10 \mu \mathrm{M}$ isradipine $(n=3)$ and enhanced by $10 \mu \mathrm{M}$ Bay $\mathrm{K}(n=1)$, confirming that $\mathrm{Ca}^{2+}$ influx does indeed occur at the presynaptic terminals through L-type $\mathrm{Ca}^{2+}$ channels.

Using OG5, we examined the relationship between $\left[\mathrm{Ca}^{2+}\right]_{\mathrm{i}}$ rise and $\mathrm{Ca}^{2+}$ influx. Given the very small decay of $I_{\mathrm{Ca}}$, this relationship could simply be obtained by varying pulse duration. Figure $6 A a$ illustrates at high magnification a sequence of images of three boutons acquired every $54 \mathrm{msec}$. A basal image is shown in the first panel of Figure $6 A a$, and the subsequent panels correspond to the first three images after a $50 \mathrm{msec}$ depolarizing pulse. The corresponding $\Delta F / F_{\mathrm{o}}$ and $I_{\mathrm{Ca}}$ plots are displayed in Figure 6, $A b$ and $A c$, respectively. In this experiment, as in other cells tested, depolarization-induced $\left[\mathrm{Ca}^{2+}\right]_{\mathrm{i}}$ transients peaked within one image for 10-50 msec pulses, limited by the sampling rate (54 msec/image). For $100-500 \mathrm{msec}$ pulses, $\left[\mathrm{Ca}^{2+}\right]_{\mathrm{i}}$ peaked at the image corresponding to the end of the pulse (Fig. 6B). The relationship between pulse duration and peak $\Delta F / F_{\mathrm{o}}$ was linear throughout the range explored (Fig. $7 D$ ). For $50 \mathrm{msec}$ pulses, OG5 $\left[\mathrm{Ca}^{2+}\right]_{\mathrm{i}}$ transients decayed to $50 \%$ of their maximum at $430 \pm 50 \mathrm{msec}(n=14)$.

Because the use of low-affinity dyes could hinder the detection of minor changes in $\left[\mathrm{Ca}^{2+}\right]_{\mathrm{i}}$ in the axon and soma, the highaffinity $\mathrm{Ca}^{2+}$ indicator OG1 $\left(K_{\mathrm{d}}, \sim 170 \mathrm{nM}\right.$ according to Molecular Probes) was used. This dye could theoretically enable the detection of changes in $\left[\mathrm{Ca}^{2+}\right]_{i}$ that would otherwise have been too small to be reported by OG5. OG1 was used only at a low concentration $(50 \mu \mathrm{M})$ to minimize the effect of adding such a high-affinity $\mathrm{Ca}^{2+}$ buffer. This indicator proved to be sensitive to changes in fluorescence in terminals evoked by $5 \mathrm{msec}$ depolarizing pulses. Pulses of durations ranging from 5 to $250 \mathrm{msec}$ that led to clear increases in terminal $\Delta F / F_{\mathrm{o}}$ failed to produce any detectable changes in the axon and soma, however. Figure $7 \mathrm{~A}$ presents an example with a $50 \mathrm{msec}$ pulse (note that measurements in the dendrites could not be performed because of the out-of-focus contaminating fluorescence contributed by the pipette). In this set of experiments, faster time resolution (one image every $13 \mathrm{msec}$ ) was achieved by pixel binning (see Materials and Methods). For short-duration pulses (5-50 msec), both $I_{\mathrm{Ca}}$ and $\left[\mathrm{Ca}^{2+}\right]_{\mathrm{i}}$ transients peaked at the end of the pulse, and the 

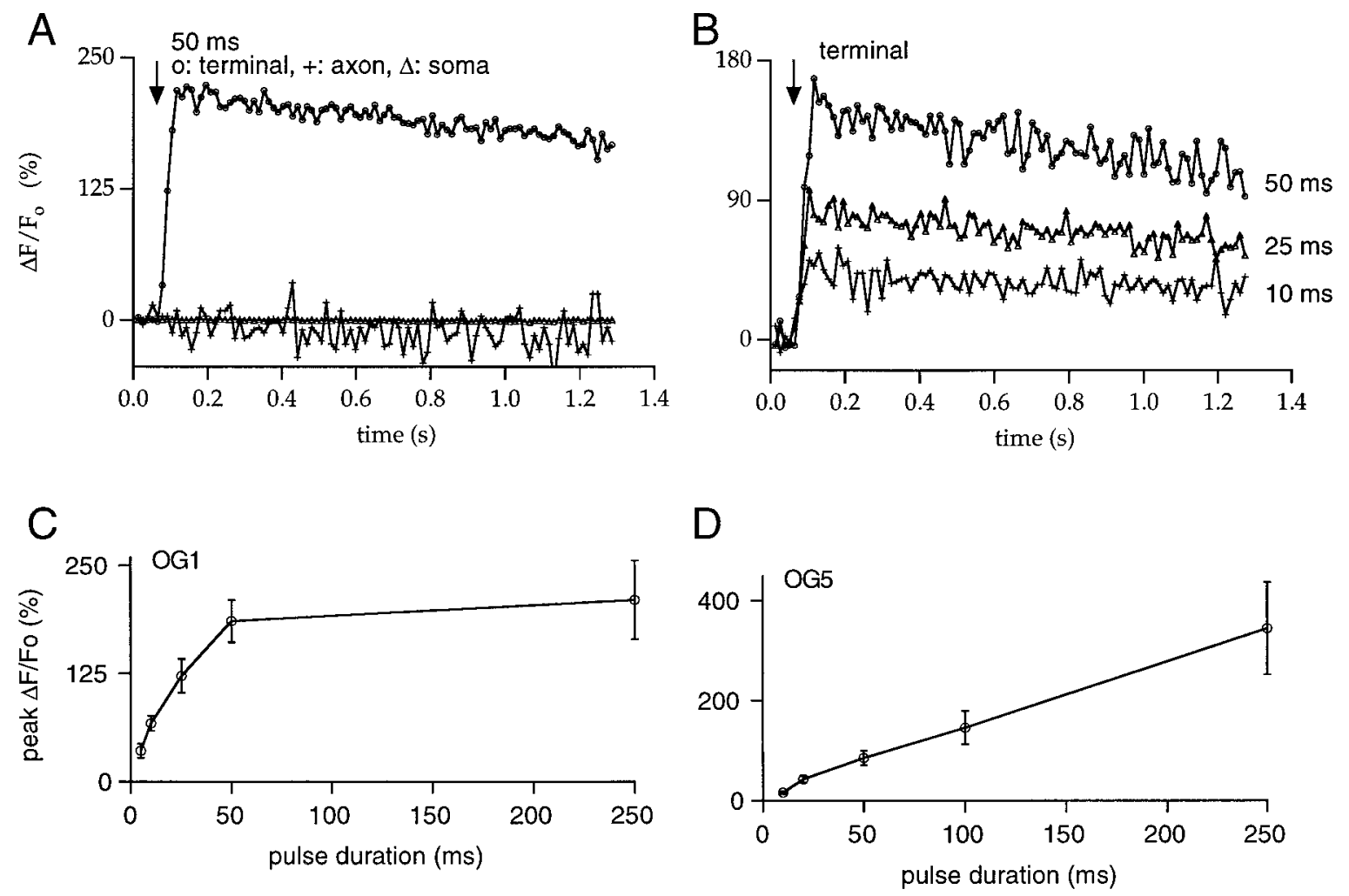

Figure 7. Properties of the $\left[\mathrm{Ca}^{2+}\right]_{\mathrm{i}}$ rises measured with low- and high-affinity $\mathrm{Ca}^{2+}$ indicators. $A$, The spatial distribution of the relative changes in fluorescence reported by the high-affinity indicator OG1 $(50 \mu \mathrm{M})$ is similar to that observed with OG5. A $50 \mathrm{msec}$ depolarization to $-20 \mathrm{mV}$ from a $\mathrm{V}_{\mathrm{h}}$ of $-70 \mathrm{mV}$ results in increases in fluorescence exclusively localized to the synaptic terminal, with no detectable changes in either the axon or the soma. $B$, In the synaptic terminal, the percent of change in OG1 fluorescence increased with pulse duration. $C$, Pooled data (4-10 cells) on the relationship between the peak percent of change in fluorescence at synaptic terminals and the duration of the depolarizing pulse for experiments performed with $50 \mu \mathrm{M}$ OG1. Note that the responses obtained with this high-affinity indicator saturate for pulses $>50 \mathrm{msec}$. In contrast, as shown in $D$, the low-affinity indicator OG5 $(200 \mu \mathrm{M})$ responds linearly throughout the duration range studied (pooled data from 5-17 cells). In $C$ and $D$, error bars indicate SEM.

relationship between peak $\Delta F / F_{\mathrm{o}}$ and pulse duration was linear (Fig. $7 B$ ) as with OG5 (Fig. 7, compare $C, D$, pooled data for OG1 and OG5). For longer depolarizations, however, fluorescence signals detected with OG1 saturated (Fig. $7 C$ ). In six cells, the decay time to $50 \%$ of peak $\Delta F / F_{\mathrm{o}}$ for $25 \mathrm{msec}$ pulses was rather variable, ranging from 0.6 to $>1.2 \mathrm{sec}$, the time at which data collection was stopped. These values were consistently larger than those measured for $50 \mathrm{msec}$ pulses with OG5, in accord with previous comparisons of the time course of $\left[\mathrm{Ca}^{2+}\right]_{i}$ transients in synaptic terminals using low- and high-affinity $\mathrm{Ca}^{2+}$ indicators (Regehr and Atluri, 1995; DiGregorio and Vergara, 1997; Helmchen et al., 1997; Sinha et al., 1997).

\section{$\left[\mathrm{Ca}^{2+}\right]_{i}$ rises restricted to terminals are specific to $\mathrm{RBCs}$}

Further support for a presynaptic locus for the sites of $\mathrm{Ca}^{2+}$ entry was derived from recordings obtained in neurons lacking synaptic terminals. Occasionally, bipolar cells having normal-looking somata and axons but lacking presynaptic boutons were encountered, probably because the axon was cut during the slicing procedure. Figure $8 A a$ shows an image taken after recordings had been performed in two cells, the somata of which were located in the INL. One of the cells has a clear synaptic bouton (and a normal $I_{\mathrm{Ca}}$ was recorded from it), whereas the other (upper quadrant of Fig. $8 A a$ ) has an axon that descends toward the ganglion cell layer but lacks a synaptic terminal. This cell had passive properties similar to those of RBCs, but it did not show inward currents in response to depolarizations (Fig. 8Ab). In such cells no fluorescence transients were observed either at the soma or at the axon (data not shown).

Although the present study focuses on RBCs, we searched for CBCs to compare their $\left[\mathrm{Ca}^{2+}\right]_{\mathrm{i}}$ signaling with that of RBCs. Despite the fact that $50 \%$ of the bipolar cells in the rat retina are cone bipolars (Euler and Wässle, 1995), the probability of recording from a CBC was extremely low in the present study. Of 72 bipolar cells recorded, only four were $\mathrm{CBCs}(6 \%)$ according to the stratification level of their axon, the branching pattern, and the presence of multiple synaptic terminals (Euler and Wässle, 1995). Three of these cells exhibited inactivating $I_{\mathrm{Ca}}$, whereas one had L-type $I_{\mathrm{Ca}} \cdot\left[\mathrm{Ca}^{2+}\right]_{\mathrm{i}}$ dynamics were clearly different from those of RBCs. Figure $8 B$ shows an experiment from one of these cells. The branching pattern and stratification of the axon in the IPL (Fig. $8 \mathrm{Ba}$ ) suggests that this cell is a cone bipolar, presumably of type 6,7 , or 8 as described by Euler and Wässle (1995). With a CsGlu internal solution, depolarization to the maximal activation voltage for $I_{\mathrm{Ca}}$ elicited strongly inactivating inward currents (Fig. $8 \mathrm{Bb}$ ) that were considerably larger than the average found for $\mathrm{RBCs} .\left[\mathrm{Ca}^{2+}\right]_{\mathrm{i}}$ rises were detected in all synaptic boutons and the proximal axon, but not in the soma (Fig. $8 B c$ ). The changes in axonal $\left[\mathrm{Ca}^{2+}\right]_{\mathrm{i}}$ had a slower rise time than those at synaptic boutons, and their magnitude decreased with the distance from the boutons. It is thus possible that axonal $\left[\mathrm{Ca}^{2+}\right]_{i}$ rises in CBCs result largely from diffusion of $\mathrm{Ca}^{2+}$ from the terminals. Whether this explanation holds true, the spatial profile of $\left[\mathrm{Ca}^{2+}\right]_{\mathrm{i}}$ rises is strikingly different from that obtained for RBCs. 

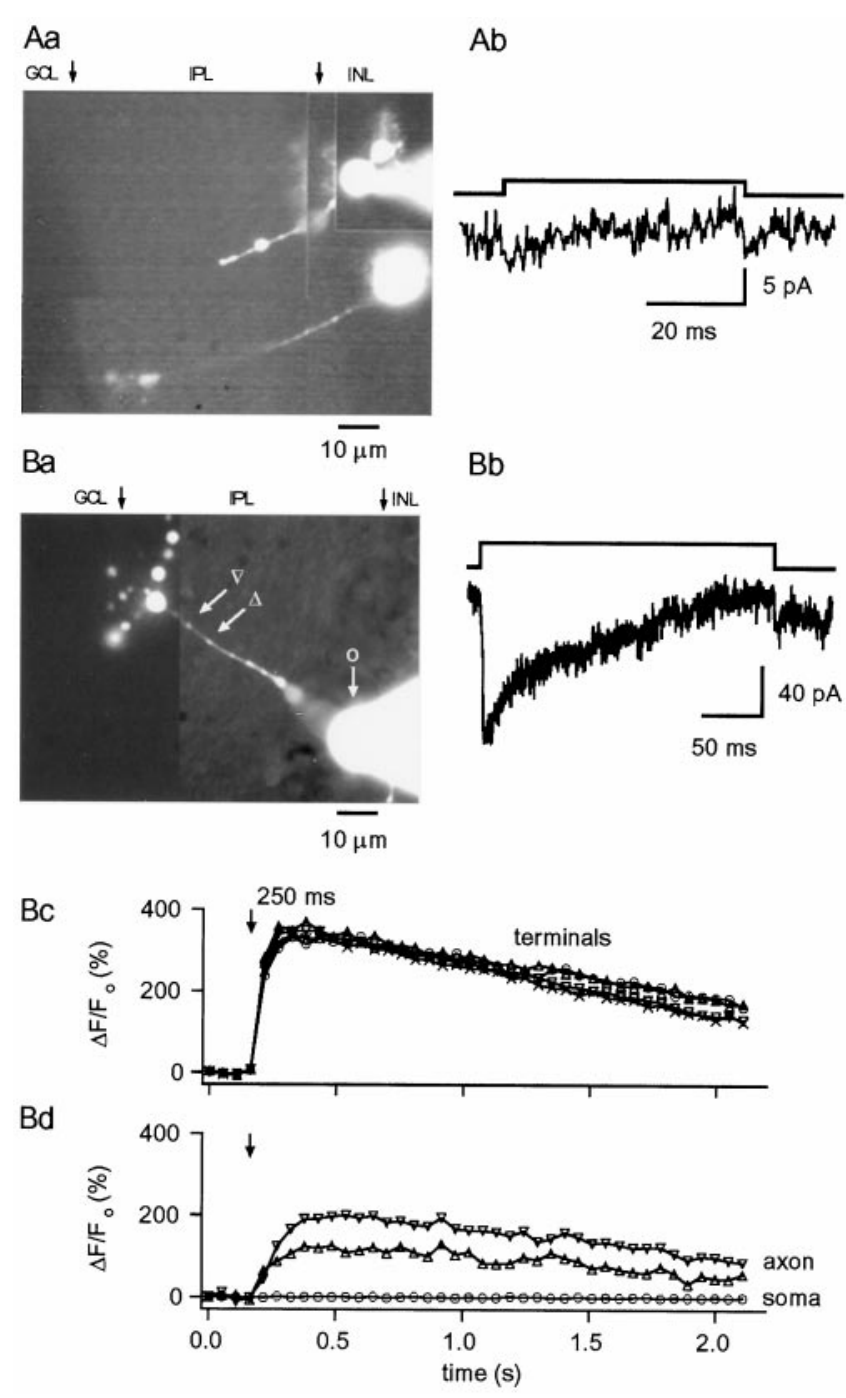

Figure 8. A, Lack of $I_{\mathrm{Ca}}$ in RBCs lacking terminals. Aa, Photomontage of an area of a retinal slice in which two bipolar cells were recorded; the top cell (with the pipette attached to its soma) lacks part of the axon and the terminal, and depolarizing pulses to $-20 \mathrm{mV}$ from a $\mathrm{V}_{\mathrm{h}}$ of $-70 \mathrm{mV}$ failed to elicit $I_{\mathrm{Ca}}(A b)$. Internal solution was CsGlu. $B, I_{\mathrm{Ca}}$ and $\left[\mathrm{Ca}^{2+}\right]_{\mathrm{i}}$ rises in CBCs. $B a$, Photomontage from OG5 fluorescence images showing a CBC with numerous synaptic terminals. $B b$, The $I_{\mathrm{Ca}}$ elicited in this cell (internal solution was CsGlu) by $250 \mathrm{msec}$ depolarizing pulses to $-30 \mathrm{mV}$ from a $\mathrm{V}_{\mathrm{h}}$ of $-70 \mathrm{mV}$ shows pronounced inactivation. $B c, B d$, Depolarization-evoked change in fluorescence were not only observed in the bipolar terminals but also in the enlarged regions of the axon. No changes were detected in the soma. Internal solution was CsGlu ( $200 \mu \mathrm{M}$ OG5, no EGTA). Photomontages in $A a$ and $B a$ were constructed from images taken at the end of the experiments, as detailed in Materials and Methods. Arrows indicate the approximate boundaries of the different layers identified under transmitted illumination. $I N L$, Inner nuclear layer; $I P L$, inner plexiform layer; $G C L$, ganglion cell layer.

\section{DISCUSSION}

We show that in mammalian retinal slices, not only are somatic recordings feasible, but terminal patch-clamp recording is also possible from RBCs. The relatively large presynaptic structure of RBCs allowed us to compare the $I_{\mathrm{Ca}}$ obtained through direct terminal recordings with that measured via somatic recordings. Further experiments will unveil whether capacitance measurements can be achieved to provide information about the exocytotic and endocytotic processes.

\section{$\mathrm{Ca}^{2+}$ currents in RBCs are mediated by HVA L-type calcium channels}

In this study we have shown that $\mathrm{RBC}$ sossess $\mathrm{HVA} \mathrm{Ca}^{2+}$ channels, the activation of which gives rise to highly localized $\left[\mathrm{Ca}^{2+}\right]_{\mathrm{i}}$ rises in the presynaptic terminals. We found a complete absence of a transient $I_{\mathrm{Ca}}$ but found the presence of an HVA calcium current that inactivates very slowly and is sensitive to DHP antagonists and agonists. This evidence thereby points to the L-type $\mathrm{Ca}^{2+}$ channel as mediating this current. In contrast, three of four recordings from $\mathrm{CBC}$ s exhibited pronounced inactivation for $I_{\mathrm{Ca}}$. In isolated mouse bipolar cells, T-type channels have been reported to mediate $\mathrm{Ca}^{2+}$ influx; $I_{\mathrm{Ca}}$ inactivates rapidly, and it is insensitive to both DHP agonists and antagonists, as well as to low $\mathrm{Cd}^{2+}$ concentrations (Kaneko et al., 1989). Recently, a study of mouse bipolar cells in slices ascertained the additional presence of a DHP-sensitive component of $I_{\mathrm{Ca}}$ (de la Villa et al., 1998). Neither of these studies attempted to identify the cell type (rod vs cone) recorded, however. It is worth noting that there are at least nine types of CBCs in the rat retina (Euler and Wässle, 1995). Heterogeneity on the distribution of $\mathrm{Ca}^{2+}$ channel types among CBCs might explain the apparent discrepancies between our results and those obtained from mice.

Our results are in agreement with those of Pan and Lipton (1995), who reported that L-type $\mathrm{Ca}^{2+}$ channels mediate the $\left[\mathrm{Ca}^{2+}\right]_{\mathrm{i}}$ rises induced by $\mathrm{K}^{+}$depolarization in the presynaptic terminals of isolated rat bipolar cells. Moreover, the combined application of voltage-clamp and imaging techniques to RBCs in slices strengthens the evidence that L-type calcium channels are the permeability pathway for $\mathrm{Ca}^{2+}$ ions in this cell type.

\section{Terminal recordings support a preferential localization} of $\mathrm{Ca}^{2+}$ channels in presynaptic terminals

The amplitude, inactivation kinetics, and pharmacological properties of $I_{\mathrm{Ca}}$ in RBCs were closely similar for recordings obtained from the soma and the presynaptic terminals. In terminal recordings, however, the $I-V$ relationship was slightly shifted to the right of the voltage axis (both activation threshold and peak), and no escape of voltage clamp was observed in the presence of Bay $\mathrm{K}$, indicating a more accurate membrane voltage control. A similar distinction for somatic and terminal recordings has been observed in goldfish Mb1 cells. A shift to the right of $\sim 8 \mathrm{mV}$ for activation threshold and $\sim 12 \mathrm{mV}$ for the peak of $I_{\mathrm{Ca}}$ was detected when comparing somatic with terminal recordings (Mennerick et al., 1997). Mennerick et al. (1997) modeled these cells as two compartments, soma and terminal (the latter possessing almost the totality of the $\mathrm{Ca}^{2+}$ channels), bridged by the axonal axial resistance, and found similar shifts in $I_{\mathrm{Ca}}$ kinetics when simulating recordings with a pipette placed either at the terminal or at the soma, consistent with our experimental observations.

Our finding that presynaptic L-type $\mathrm{Ca}^{2+}$ channels mediate the $\mathrm{Ca}^{2+}$ influx responsible for neurotransmitter release in mammalian RBCs is in agreement with the role of this channel type in other neurons that release neurotransmitter in a graded manner. A similar function has been ascribed to L-type $\mathrm{Ca}^{2+}$ channels in Mb1 bipolar cells (Tachibana et al., 1993; Heidelberger et al., 1994; von Gersdorff and Matthews, 1994; Sakaba et al., 1997), mammalian outer hair cells (Nakagawa et al., 1991), salamander rods (Corey et al., 1984), and lizard cones (Maricq and Korenbrot, 1988). The slow inactivation rate of these L-type currents differs from that in myocytes (Hadley and Lederer, 1991) and hippocampal neurons (Köhr and Mody, 1991) in which $I_{\mathrm{Ca}}$ inactivates in the tens of milliseconds range. It is similar to that of $I_{\mathrm{Ca}}$ 
in goldfish bipolar terminals (von Gersdorff and Matthews, 1996) in which both a tonic and a phasic mode of exocytosis (Mennerick and Matthews, 1996; von Gersdorff and Matthews, 1997) and subsequent neurotransmitter release occur (Tachibana et al., 1993; Sakaba et al., 1997). Thus, slowly inactivating L-type $\mathrm{Ca}^{2+}$ channels seem to be more adequate for synapses that must handle both phasic and graded signal transmission (Juusola et al., 1996) rather than $\mathrm{N}$ or $\mathrm{P} / \mathrm{Q}$ subtypes that inactivate more rapidly and operate at synapses with strictly transient transmission such as the calyces of Held (Takahashi et al., 1996), the chick ciliary ganglion (Stanley and Goping, 1991; Yawo and Momiyama, 1993), and other CNS synapses (Dunlap et al., 1995).

\section{Inhibitory negative feedback}

A remarkable characteristic in some of our recordings was the presence of transient outward currents superimposed on the inward $\mathrm{Ca}^{2+}$ fluxes elicited by depolarization. The low-chloride internal solution used in our experiments resembles the physiological ionic composition; in these conditions, outward currents carried by $\mathrm{Cl}^{-}$would lead to a hyperpolarization, which would, in turn, shut down the $\mathrm{Ca}^{2+}$ conductance and transform a sustained response into a transient one, consistent with the reported light responses in rabbit RBCs (Raviola and Dacheux, 1987). The sensitivity of these outward currents to $\mathrm{GABA}_{\mathrm{A}}, \mathrm{GABA}_{\mathrm{C}}$, and glycine antagonists indicates that they arise from reciprocal feedback synapses. Morphological studies have established that RBCs make a dyad synapse in the IPL onto both GABAergic A17 amacrine cells and glycinergic AII amacrine cells (Kidd, 1962; Dowling and Boycott, 1966; Wässle and Boycott, 1991). It has been shown that both cell types contain synaptic vesicles in the dendritic processes facing the rod bipolar endings with a higher vesicle density in the A17 (Raviola and Dacheux, 1987).

Furthermore, the presence of both GABA and glycine receptors in the synaptic terminals of mammalian RBCs has been largely demonstrated. Both neurotransmitters applied locally to the axonal endings elicit bicuculline-, picrotoxin-, and strychninesensitive $\mathrm{Cl}^{-}$currents (Karschin and Wässle, 1990; Suzuki et al., 1990). Electrophysiological studies have shown that RBCs express $\mathrm{GABA}_{\mathrm{A}}$ and $\mathrm{GABA}_{\mathrm{C}}$ receptors (Feigenspan et al., 1993), and the presence of the GABA $\rho$ subunit in these cells was further confirmed by the combined use of patch-clamp recordings with single cell RT-PCR (Yeh et al., 1996). Finally, GABA inhibits $\mathrm{Ca}^{2+}$ influx into RBC terminals via activation of $\mathrm{GABA}_{\mathrm{A}}$ and $\mathrm{GABA}_{\mathrm{C}}$ receptors (Pan and Lipton, 1995), and these two receptor types have been detected immunocytochemically in endings of rod bipolars (Greferath et al., 1995; Enz et al., 1996; Koulen et al., 1998). This combined evidence therefore supports the interpretation of our data that amacrine cells, via reciprocal feedback synapses on RBCs, are responsible for the outward current transients elicited by $\mathrm{Ca}^{2+}$ entry. Similar findings consistent with this hypothesis have been recently reported in abstract form (Hartveit, 1997). The low frequency of occurrence of such reciprocal synaptic currents in the present experiments is likely to result from disruption of synaptic connections during the slicing procedure at the slice surface where recordings were obtained.

\section{$\mathrm{Ca}_{\mathrm{i}}$ rises in $\mathrm{RBCs}$ are restricted to presynaptic terminals}

The measurements with $\mathrm{Ca}^{2+}$ indicators confirm that $\mathrm{Ca}^{2+}$ influx in RBCs is restricted to the presynaptic terminals, with no detectable influx in the soma or axon. Along with the similarity in activation kinetics of $I_{\mathrm{Ca}}$ observed at the two recording sites, these findings suggest that RBCs possess a compact electrotonic structure that allows a passive spread of the voltage signal from the somatodendritic domain to the synaptic terminals where L-type $\mathrm{Ca}^{2+}$ channels are preferentially located to mediate tonic transmitter release.

The complete absence of $\left[\mathrm{Ca}^{2+}\right]_{\mathrm{i}}$ rises in $\mathrm{RBC}$ axons contrasts with findings in other central neurons. Imaging studies have shown that the large depolarization-evoked $\left[\mathrm{Ca}^{2+}\right]_{i}$ rises occurring at synaptic varicosities in cortical neurons (Mackenzie et al., 1996) and cerebellar interneurons (Llano et al., 1997) are accompanied by smaller changes in $\left[\mathrm{Ca}^{2+}\right]_{i}$ in the axonal regions between varicosities. These changes presumably originate from the redistribution of $\mathrm{Ca}^{2+}$ ions that takes place after a $\left[\mathrm{Ca}^{2+}\right]_{i}$ rise. Furthermore, clear changes in $\left[\mathrm{Ca}^{2+}\right]_{\mathrm{i}}$ take place in the preterminal region of the calyces of Held (Borst et al., 1995), in the axon initial segment of neocortical pyramidal neurons (Schiller et al., 1995), and in the proximal axon of cerebellar Purkinje cells (Callewaert et al., 1996) after a single action potential. In our experiments, no detectable $\left[\mathrm{Ca}^{2+}\right]_{\mathrm{i}}$ rise was obtained in $\mathrm{RBC}$ axons at close distances to the terminals, even for rather long depolarizations. This finding suggests a highly effective system for $\mathrm{Ca}^{2+}$ removal, ensuring that $\mathrm{Ca}^{2+}$ ions are cleared from the axonal cytoplasm at a rate similar to that of $\mathrm{Ca}^{2+}$ diffusion into the axon. The axonal-terminal segregation of $\left[\mathrm{Ca}^{2+}\right]_{\mathrm{i}}$ rises seems to be particular to RBCs, because CBCs showed clear axonal $\mathrm{Ca}_{\mathrm{i}}$ rises in response to depolarizations. Diffusion from the presynaptic boutons is likely to account for the axonal $\left[\mathrm{Ca}^{2+}\right]_{\mathrm{i}}$ signals, because they were delayed with respect to the terminal signals. It is worth noting, however, that the absence of axonal sites for $\mathrm{Ca}^{2+}$ influx deduced from the present work is not consistent with the presence of synaptic ribbons along the axons of several different types of CBCs, as well as in axons of RBCs in the cat retina (McGuire et al., 1984). Detailed exploration of bipolar cell axons at the electron microscopic level in the rat retina will be required to settle this issue.

\section{REFERENCES}

Barnes-Davies M, Forsythe ID (1995) Pre- and postsynaptic glutamate receptors at a giant excitatory synapse in rat auditory brainstem slices. J Physiol (Lond) 488:387-406.

Borst JGG, Helmchen F, Sakmann B (1995) Pre- and postsynaptic whole-cell recordings in the medial nucleus of the trapezoid body of the rat. J Physiol (Lond) 489:825-840.

Callewaert G, Eilers J, Konnerth A (1996) Axonal calcium entry during fast sodium action potentials in rat cerebellar Purkinje neurones. J Physiol (Lond) 495:641-647.

Corey DP, Dubinsky JM, Schwartz EA (1984) The calcium current in the inner segments of rods in the salamander (Ambystoma tigrinum) retina. J Physiol (Lond) 354:557-575.

de la Villa P, Vaquero CF, Kaneko A (1998) Two types of calcium currents of the mouse bipolar cells recorded in the retinal slice preparation. Eur J Neurosci 10:317-323.

DiGregorio D, Vergara J (1997) Localized detection of action potentialinduced presynaptic calcium transients at a Xenopus neuromuscular junction. J Physiol (Lond) 505:585-592.

Dowling JE, Boycott BB (1966) Organization of the primate retina: electron microscopy. Proc R Soc Lond B Biol Sci 166:80-111.

Dunlap K, Luebke JI, Turner TJ (1995) Exocytotic $\mathrm{Ca}^{2+}$ channels in mammalian central neurons. Trends Neurosci 18:89-98.

Enz R, Brandstatter JH, Wässle H, Bormann J (1996) Immunocytochemical localization of the GABAc receptor rho subunits in the mammalian retina. J Neurosci 16:4479-4490.

Euler T, Wässle H (1995) Immunocytochemical identification of cone bipolar cells in the rat retina. J Comp Neurol 361:461-478.

Feigenspan A, Wässle H, Bormann J (1993) Pharmacology of GABA receptor $\mathrm{Cl}^{-}$channels in rat retinal bipolar cells. Nature 361:159-162. Greferath U, Grunert U, Fritschy JM, Stephenson A, Mohler H, Wässle 
H (1995) GABAA receptor subunits have differential distributions in the rat retina: in situ hybridization and immunohistochemistry. J Comp Neurol 353:553-571.

Hadley RW, Lederer WJ (1991) $\mathrm{Ca}^{2+}$ and voltage inactivate $\mathrm{Ca}^{2+}$ channels in guinea-pig ventricular myocytes through independent mechanisms. J Physiol (Lond) 444:257-268.

Hamill OP, Marty A, Neher E, Sakmann B, Sigworth FJ (1981) Improved patch-clamp techniques for high-resolution current recording from cells and cell-free membrane patches. Pflügers Arch 391:85-100.

Hartveit E (1997) Reciprocal synaptic transmission between rod bipolar cells and amacrine cells in the rat retina. Soc Neurosci Abstr 23:450.

Heidelberger R, Matthews G (1992) Calcium influx and calcium current in single synaptic terminals of goldfish retinal bipolar neurons. J Physiol (Lond) 447:235-256.

Heidelberger R, Heinemann C, Neher E, Matthews G (1994) Calcium dependence of the rate of exocytosis in a synaptic terminal. Nature 371:513-515.

Helmchen F, Borst JG, Sakmann B (1997) Calcium dynamics associated with a single action potential in a CNS presynaptic terminal. Biophys $\mathrm{J}$ 72:1458-1471.

Juusola M, French AS, Uusitalo RO, Weckstrom M (1996) Information processing by graded-potential transmission through tonically active synapses. Trends Neurosci 19:292-297.

Kaneko A, Pinto LH, Tachibana M (1989) Transient calcium current of retinal bipolar cells of the mouse. J Physiol (Lond) 410:613-629.

Karschin A, Wässle H (1990) Voltage- and transmitter-gated currents in isolated rod bipolar cells of rat retina. J Neurophysiol 63:860-876.

Kidd M (1962) Electron microscopy of the inner plexiform layer of the retina in the cat and pigeon. $\mathrm{J}$ Anat 96:179-188.

Klumpp DJ, Song EJ, Ito S, Sheng MH, Jan LY, Pinto LH (1995) The Shaker-like potassium channels of the mouse rod bipolar cell and their contributions to the membrane current. J Neurosci 15:5004-5013.

Köhr G, Mody I (1991) Endogenous intracellular calcium buffering and the activation/inactivation of HVA calcium currents in rat dentate gyrus granule cells. J Gen Physiol 98:941-967.

Koulen P, Brandstätter JH, Enz R, Bormann J, Wässle H (1998) Synaptic clustering of $\mathrm{GABA}_{\mathrm{c}}$ receptors $\rho$ subunits in the rat retina. Eur J Neurosci 10:115-127.

Llano I, Tan YSP, Caputo C (1997) Spatial heterogeneity of intracellular $\mathrm{Ca}^{2+}$ signals in axons of basket cells from rat cerebellar slices. J Physiol (Lond) 502:509-519.

Mackenzie PJ, Umemiya M, Murphy TH (1996) $\mathrm{Ca}^{2+}$ imaging of CNS axons in culture indicates reliable coupling between single action potentials and distal functional release sites. Neuron 16:783-795.

Maricq AV, Korenbrot JI (1988) Calcium and calcium-dependent chloride currents generate action potentials in solitary cone photoreceptors. Neuron 1:503-515.

McCleskey EW (1994) Calcium channels: cellular roles and molecular mechanisms. Curr Opin Neurobiol 4:304-312.

McGuire BA, Stevens JK, Sterling P (1984) Microcircuitry of bipolar cells in cat retina. J Neurosci 4:2920-2938.

Mennerick S, Matthews G (1996) Ultrafast exocytosis elicited by calcium current in synaptic terminals of retinal bipolar neurons. Neuron 17:1241-1249.

Mennerick S, Zenisek D, Matthews G (1997) Static and dynamic membrane properties of large-terminal bipolar cells from goldfish retina: experimental test of a compartment model. J Neurophysiol 78:51-62.

Nakagawa T, Kakehata S, Akaike N, Komune S, Takasaka T, Uemura T (1991) Calcium channel in isolated outer hair cells of guinea pig cochlea. Neurosci Lett 125:81-84.

Nomura A, Shigemoto R, Nakamura Y, Okamoto N, Mizuno N, Nakanishi S (1994) Developmentally regulated postsynaptic localization of a metabotropic glutamate receptor in rat rod bipolar cells. Cell 77:361-369.

Nowycky MC, Fox AP, Tsien RW (1985) Long-opening mode of gating of neuronal calcium channels and its promotion by the dihydropyridine calcium agonist Bay K 8644. Proc Natl Acad Sci USA 82:2178-2182.

Okada T, Horiguchi H, Tachibana M (1995) $\mathrm{Ca}^{2+}$-dependent $\mathrm{Cl}^{-}$current at the presynaptic terminals of Goldfish retinal bipolar cells. Neurosci Res 23:297-303.

Pan ZH, Lipton SA (1995) Multiple GABA receptor subtypes mediate inhibition of calcium influx at rat retinal bipolar cell terminals. J Neurosci 15:2668-2679.
Protti DA, Llano I (1997) Calcium currents in rat rod bipolar cell occur in the presynaptic terminals. Soc Neurosci Abstr 23:447.

Protti DA, Gerschenfeld HM, Llano I (1997) GABAergic and glycinergic IPSCs in ganglion cells of rat retinal slices. J Neurosci 17:6075-6085.

Randall A, Tsien RW (1995) Pharmacological dissection of multiple types of $\mathrm{Ca}^{2+}$ channel currents in rat cerebellar granule neurons. J Neurosci 15:2995-3012.

Raviola E, Dacheux RF (1987) Excitatory dyad synapse in rabbit retina. Proc Natl Acad Sci USA 84:7324-7328.

Regehr WG, Atluri PP (1995) Calcium transients in cerebellar granule cell presynaptic terminals. Biophys J 68:2156-2170.

Regehr WG, Tank DW (1994) Dendritic calcium dynamics. Curr Opin Neurobiol 4:373-382.

Sakaba T, Tachibana M, Matsui K, Minami N (1997) Two components of transmitter release in retinal bipolar cells: exocytosis and mobilization of synaptic vesicles. Neurosci Res 27:357-370.

Schiller J, Helmchen F, Sakmann B (1995) Spatial profile of dendritic calcium transients evoked by action potentials in rat neocortical pyramidal neurones. J Physiol (Lond) 487:583-600.

Sinha SR, Wu LG, Saggau P (1997) Presynaptic calcium dynamics and transmitter release evoked by single action potentials at mammalian central synapses. Biophys J 72:637-651.

Southan AP, Robertson BR (1998) Patch-clamp recordings from cerebellar basket cell bodies and their presynaptic terminals reveal an asymmetric distribution of voltage-gated potassium channels. J Neurosci 18:948-955.

Stanley EF, Goping G (1991) Characterization of a calcium current in a vertebrate cholinergic presynaptic nerve terminal. J Neurosci 11:985-993.

Suzuki S, Tachibana M, Kaneko A (1990) Effects of glycine and GABA on isolated bipolar cells of the mouse retina. J Physiol (Lond) 421:645-662.

Tachibana M, Kaneko A (1987) gamma-Aminobutyric acid exerts a local inhibitory action on the axon terminal of bipolar cells: evidence for negative feedback from amacrine cells. Proc Natl Acad Sci USA 84:3501-3505.

Tachibana M, Okada T, Arimura T, Kobayashi K, Piccolino M (1993) Dihydropyridine-sensitive calcium current mediates neurotransmitter release from bipolar cells of the goldfish retina. J Neurosci 13:2898-2909.

Takahashi T, Forsythe ID, Tsujimoto T, Barnes-Davies M, Onodera K (1996) Presynaptic calcium current modulation by a metabotropic glutamate receptor. Science 274:594-597.

Uchitel OD (1997) Toxins affecting calcium channels in neurons. Toxicon 35:1161-1191.

von Gersdorff H, Matthews G (1994) Dynamics of synaptic vesicle fusion and membrane retrieval in synaptic terminals. Nature 367:735-739.

von Gersdorff H, Matthews G (1996) Calcium-dependent inactivation of calcium current in synaptic terminals of retinal bipolar neurons. J Neurosci 16:115-122.

von Gersdorff H, Matthews G (1997) Depletion and replenishment of vesicle pools at a ribbon-type synaptic terminal. J Neurosci 17:1919-1927.

Wässle H, Boycott BB (1991) Functional architecture of the mammalian retina. Physiol Rev 71:447-480.

Wenzel A, Benke D, Mohler H, Fritschy JM (1997) N-methyl-Daspartate receptors containing the $\mathrm{Nr} 2 \mathrm{~d}$ subunit in the retina are selectively expressed in rod bipolar cells. Neuroscience 78:1105-1112.

Yawo H, Momiyama A (1993) Re-evaluation of calcium currents in preand postsynaptic neurones of the chick ciliary ganglion. J Physiol (Lond) 460:153-172.

Yeh HH, Grigorenko EV, Veruki ML (1996) Correlation between a bicuculline-resistant response to GABA and GABAA receptor rho 1 subunit expression in single rat retinal bipolar cells. Vis Neurosci 13:283-292.

Zhang JA, Jung CS, Slaughter MM (1997) Serial inhibitory synapses in retina. Vis Neurosci 14:553-563.

Zhang JF, Randall AD, Ellinor PT, Horne WA, Sather WA, Tanabe T, Schwarz TL, Tsien RW (1993) Distinctive pharmacology and kinetics of cloned neuronal $\mathrm{Ca}^{2+}$ channels and their possible counterparts in mammalian CNS neurons. Neuropharmacology 32:1075-1088. 